\title{
LESSONS LEARNED FROM OCCURRENCE OF SINKHOLES RELATED TO MAN-MADE CAVITIES IN A TOWN OF SOUTHERN ITALY
}

\author{
Pietro Pepe, Nunzia Pentimone, Giuditta Garziano \\ Apogeo s.r.l., Via Caduti di Nassiriya 170 - 70022, Altamura, Italy, http://www.apogeo.biz \\ Vincenzo Martimucci \\ Comune di Altamura, Italy, sindaco@comune.altamura.ba.it
}

Mario Parise

CNR-IRPI,Via Amendola 122-I, 70126 Bari, Italy,m.parise@ba.irpi.cnr.it

\begin{abstract}
The presence of man-made cavities below the historical parts of towns is a common feature in large portions of Italy. Different typologies of anthropogenic cavities have been excavated in different epochs for many purposes, including research and collection of potable water, establishment of underground working sites for olive oil production, worship sites, etc. Underground quarries are probably the most diffuse typology of subterranean cavities, especially the largest ones. Originally located at the outskirts of towns, quarries are increasingly found in built up areas due to urban expansion that has characterized the last century.
\end{abstract}

This paper describes the recent occurrence of sinkholes related to underground quarries in the town of Altamura, in the Murge plateau of inland Apulia, where since 2006 a number of sinkholes have formed above subterranean calcarenite quarries, the local rock mostly used for building purposes. These quarries developed below ground because the calcarenite is generally located covered by clays (ranging in thickness from a few to 15 meters). Their abandonment, and the progressive weathering of the rock, has caused failures in the underground quarries. Eventually, such instabilities propagated upward until reaching the surface, and producing sinkholes.

Many sinkholes in Altamura have occurred within the urban area, and/or in areas of recent or proposed future constructions. As a result, in 2008 the local Authority established a new building code, requiring detailed geological studies in areas determined to be at risk in order to verify and mitigate any hazardous situations. A great amount of data has been collected in these studies in recent years, which has been organized and managed in a dedicated geo-database.

All activities used to identify the underground quarries, recognize the corresponding sinkhole-prone areas at the surface, survey the cavities, produce detailed maps, and reclaim the sites in order to allow future development, are described in this paper, as an example of how to properly manage a territory characterized by sinkhole problems.

\section{Introduction}

Altamura (Figure 1) is one of the largest towns in the High Murge of Apulia (south-east Italy), and is located in a foreland area consisting of carbonate rocks where karst is the main agent shaping the landscape (Parise, 2011). In addition to the many karst caves and surface landforms, including the Pulo, one the largest dolines in the region with a diameter of over $500 \mathrm{~m}$ and depth of $92 \mathrm{~m}$, there are several cavities of anthropogenic origin at the outskirts of town, in a sector undergoing urban expansion.

These cavities represent a significant risk to the population. Until 2006, it was commonly believed that the subterranean voids were limited to a few areas near ancient open quarries since abandoned and partly filled with solid waste. However, a number of sinkholes have developed in recent years causing safety concerns. Information on these underground man-made cavities has increased greatly in recent years, with over $16 \mathrm{~km}$ of subterranean passages explored and mapped.

The present paper describes the methodological approach used to increase the understanding of the caves and procedures have been undertaken to mitigate safety concerns. 


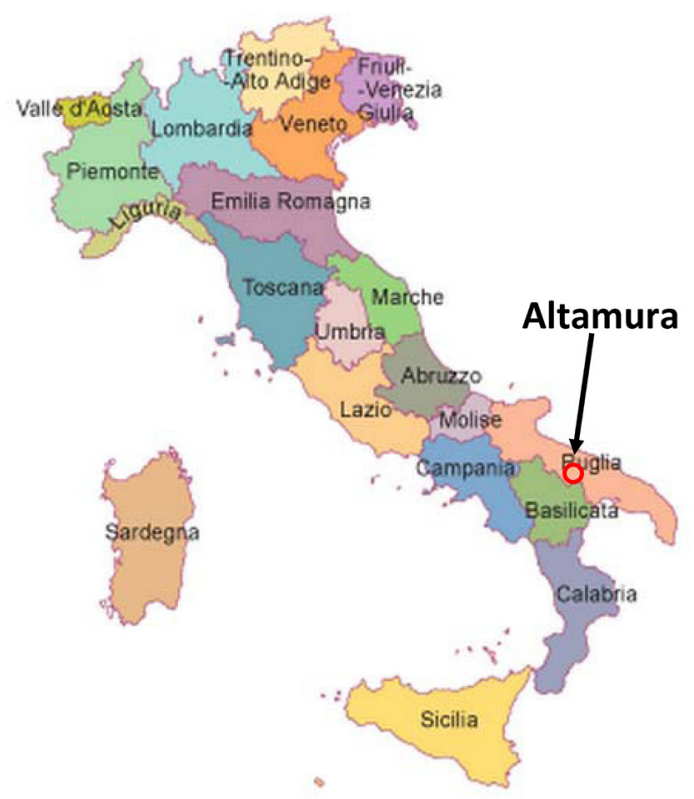

Figure 1. Location of the study area.

\section{Geological setting and legal constraints}

The man-made cavities that are the proximate cause of sinkhole formation at Altamura consist of underground quarries located at the north eastern and eastern outskirts of town (Figure 2). Their development may be hazardous in this recently urbanized area, where many buildings have been constructed in the last ten years. Only a small number of the buildings date back before 1990, and have been built using surficial foundations. Construction companies did not take into account the underground cavities until sinkholes began to develop. When cavities were found during construction, foundation piles were used to cross the cavities which often produced rock failures within the quarries.

The Altamura area rests between the southern portion of the Murge Highplain and the northern boundary of the

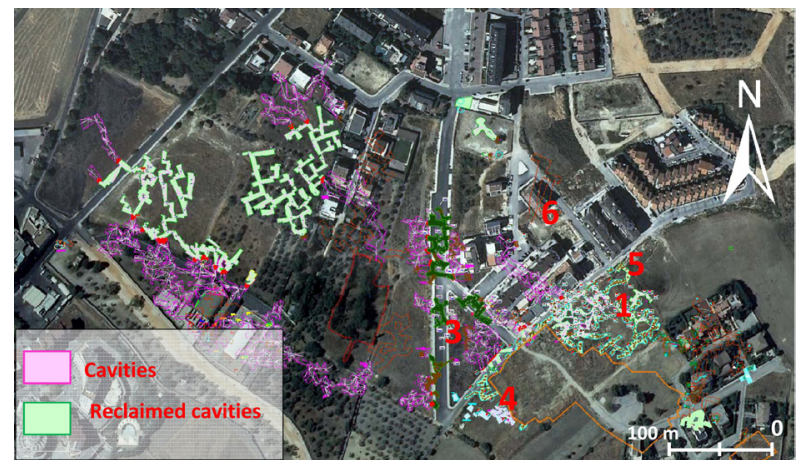

Figure 2. NE outskirts of town, and the underground quarries. Red numbers indicate the documented sinkholes (see also Table 1).
Bradano Foredeep (Azzaroli et al., 1968; Iannone \& Pieri, 1982; Ricchetti et al., 1988; Ciaranfi et al., 1988; Pieri et al., 1996; Tropeano \& Sabato, 2000). The municipality is crossed by the NW-SE topographic divide separating the Bradano River catchment from those of several karst valleys to the east, toward the Adriatic Sea.

The location of this topographic feature divides the Basin Authority of Apulia, covering the northern municipality, and the Basin Authority of Basilicata, covering the central-southern sector, including the urban area of Altamura. The town, located at the top of a ridge at $485 \mathrm{~m}$ above MSL, rests on a morphological high of tectonic origin in the Cretaceous bedrock. The areas with underground quarries, on the other hand, are located in a topographically depressed sector where limestones are covered by Miocene calcarenite and Pleistocene silt clays (Figure 3). The calcarenite rock is the object of the underground quarrying activity.

In 2008, following some sinkhole events, the Altamura Municipality issued decree no. 135/2008 obliging all building owners considered at risk to undertake a detailed geological study to verify, and eventually mitigate, all dangerous situations for both public and private properties. At the same time, the Basin Authority of Basilicata issued specific regulations for any new construction, or modification of structures already existing in the areas at risk (Fiore, 2006; Berardi et al., 2010).

These regulations included direct and indirect surveys aimed at ascertaining underground conditions, particularly the presence of voids and instability problems.

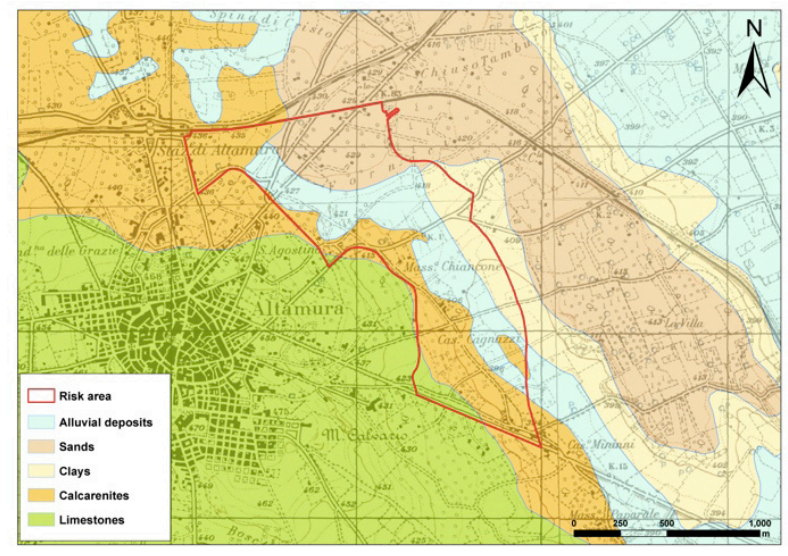

Figure 3. Geological map of study area. 


\section{Sinkhole events}

Documentation and temporal references have been found for six sinkholes in the Altamura territory (Martimucci et al., 2010; Spilotro et al., 2010; Fiore \& Parise, in press). The sinkhole locations are shown in Figure 2, whilst the dates of occurrence are listed in Table 1.

Chronologically, the first documented events (5 and 6) pre-date the year 1947, with no precise date available.

These two events were identified through multi-temporal analysis of aerial photographs. They are located in the same areas where recent sinkhole events have occurred, thus indicating that sinkhole development is a longstanding problem going back at least several decades.

Sinkhole no. 1 was registered at locality Chiancone (Via Di Vagno) in 2006 (Figure 4). It occurred near a small building built upon large diameter pilings.

The May 2007 sinkhole at Via Barcellona (no.2; Figure 5) greatly increased concern about sinkholes, focusing the attention of both authorities and the general population. It was triggered by the roof collapse of an underground calcarenite quarry. There was $15 \mathrm{~m}$ of clay overburden, which sustained a shallow aquifer. The sinkhole, of circular shape and with a diameter of $2 \mathrm{~m}$ at the surface, was $24 \mathrm{~m}$ deep, and exposed an area where the underground galleries are closely distributed.

In 2008, two sinkholes were recorded. No precise date is available for the occurrence of the first (no. 3). It is located near Via Copenaghen, and originated due to collapse of a gallery vault which had already experienced previous failures, and that had been filled with earth material.

The second sinkhole (no. 4) occurred on December 3, 2008, in Via Fornaci, and was produced when filling material of an open clay quarry dropped into an old entrance of the underground calcarenite quarry.

Table 1. List of documented sinkholes.

\begin{tabular}{|l|l|l|}
\hline id & date & locality \\
\hline 1 & March 2006 & Via Di Vagno \\
\hline 2 & May 07, 2007 & Via Barcellona \\
\hline 3 & 2008 & Via Copenaghen \\
\hline 4 & December 03, 2008 & Via Fornaci \\
\hline 5 & before 1947 & Via Fornaci \\
\hline 6 & before 1947 & Via Praga \\
\hline
\end{tabular}

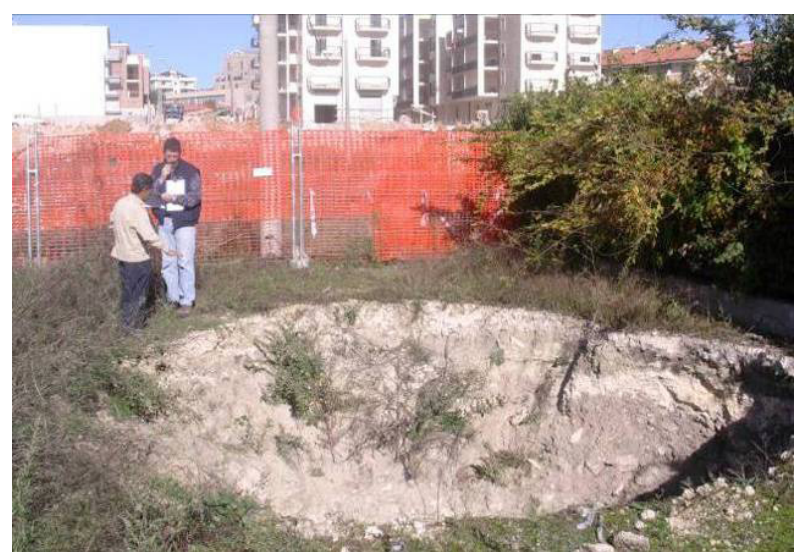

Figure 4. Sinkhole no. 1, occurred in March 2006 at Via Di Vagno.

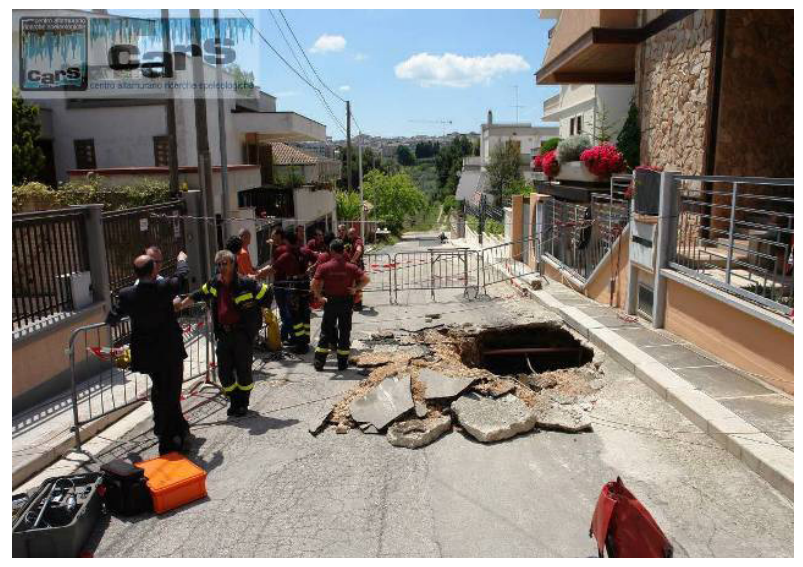

Figure 5. The sinkhole at Via Barcellona (May 07, 2007; no. 2): this was the main event at Altamura, directly affecting an area of recently-built houses.

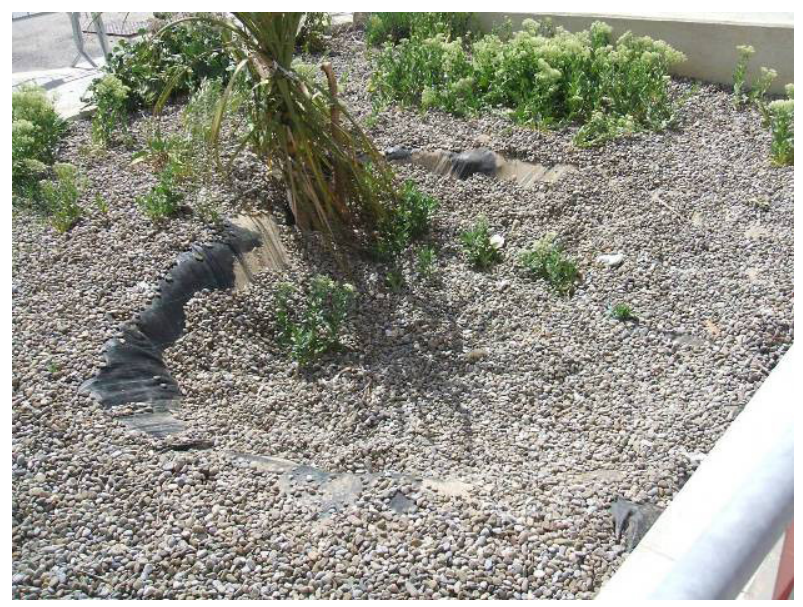

Figure 6. The sinkhole at Via Copenaghen (no. 3). 


\section{Causes of the origin of the sinkholes}

The main causes of the sinkholes at Altamura are both natural and anthropogenic. Anthropogenic activities have often accelerated processes that were occurring naturally. On the other hand, recent construction activities in the area where the underground quarries are located has highlighted a phenomenon that otherwise would have been less noticed.

\section{Lack of ventilation}

In most of the cases, access to the underground quarries has been closed off for two main reasons: man-made solid waste fill and collapse of access points. Runoff water also played a role by transporting and depositing material at the entrances, which in turn produced additional loadings over gallery vaults.

Whatever the reason, access closure impeded air circulation in the underground quarries, leading to degradation of the physical and mechanical properties of the calcarenite rock mass.

\section{Water percolation and infiltration}

Rainfall runoff is among the most significant factors producing instability in the underground quarries. It is well documented that runoff from the urban area of Altamura is discharged into the old entrances of underground quarries (Figure 7), or in topographically depressed areas.

Transport of solid materials by these waters is erosive and may, over time, change the permeability characteristics of the rock mass. This phenomenon is particularly evident along the stretch of Via la Carrera from Via Bari to Via Cassano, and in nearby areas.

\section{Deep foundations}

Pile foundations (Figure 8) have likely contributed to the development of cracks and failures in the calcarenite rock mass; at the same time, they also represent preferential pathways for water flow.

\section{Boreholes focusing runoff water}

In a few cases, boreholes below houses have been found to discharge rainfall runoff collecting in areas around the buildings.

\section{Other factors}

There are several other factors that can contribute to sinkhole formation, although generally subordinate to

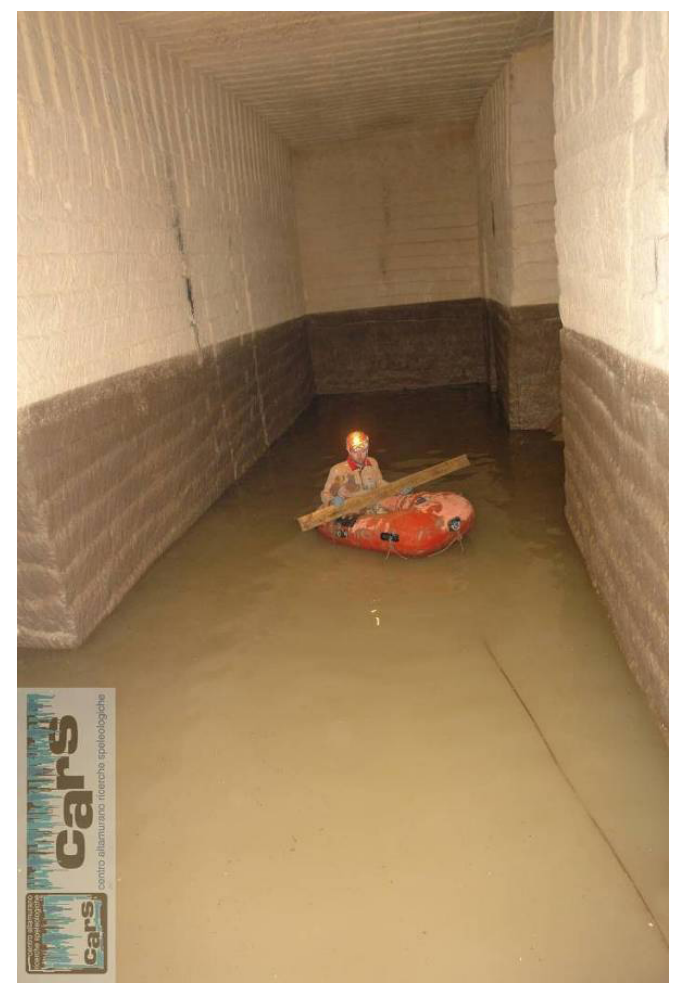

Figure 7. Flooded passage in a calcarenite underground quarry.

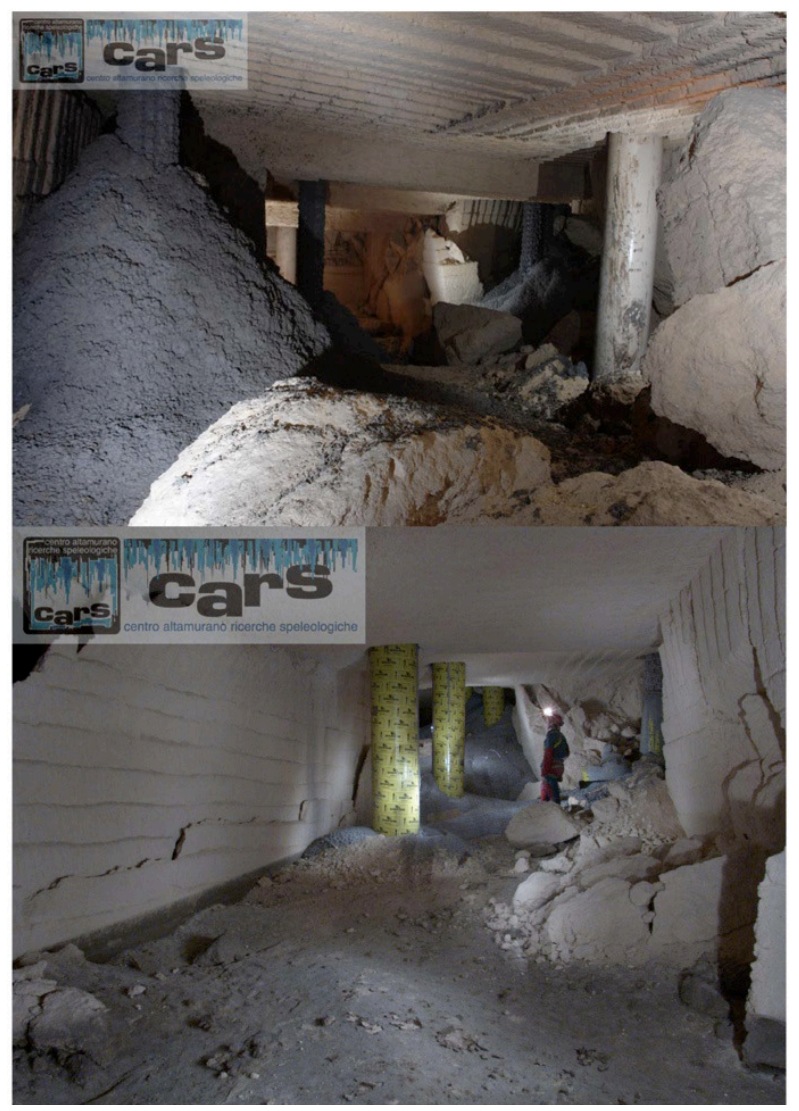

Figure 8. Foundation piles within the quarries. 
the previously discussed factors. Leakage from hydric and sewer systems is common. At several areas the sewers directly enter the underground quarries; it is well known that contact between waste waters and soft rocks such as calcarenites may have serious consequences in terms of reduction in the mechanical properties of the rock mass (Dobereiner \& De Freitas, 1986; Coop \& Atkinson, 1993; La Gioia \& Nova, 1995).

Vibrations induced by the traffic may also act in amplifying or accelerating the process of degradation in the rock mass.

Eventually, failures and falls from the vault progressively reduce the thickness of the overlying stiff calcarenite, and fill voids with the breakdown deposits. These latter are frequently of a size that can damage the piles sustaining the buildings above.

\section{Methods of study}

The methods used for the survey at Altamura are similar to those normally used for geologic explorations. Conversely, we stress that the approach followed in this study, consisting of a systematic application of surface and subsurface investigations, can produce detailed understanding of complex geologic phenomena, in spite of the inherent difficulties presented by subsurface exploration.

All of the applied methodologies were designed to gain access to the underground quarries. Our started conviction was that the precise survey and location of the underground quarries with respect to the built-up areas above was the main priority, before proceeding with the following phases of study. The surveying activities were especially complex in the urban areas where direct surveys were impossible and indirect surveys were logistically difficult. In this area the best results were obtained with indirect analyses carried out in boreholes.

\section{Indirect surveys}

Different types of geophysical methods (2D and 3D electrical tomography, georadar, seismic tomography in boreholes, etc.) are available to identify undergound voids. In the Altamura area, the complex geological setting and the high level of urbanization made surveying difficult. Thus, we developed a complex methodology based on those indirect methodologies that, in our opinion, were the most suitable to the studied setting. Due to depth of the underground spaces (greater than 15 meters) and to the presence of clays (good conductive materials) overlying the calcarenites, the georadar method did not provide good results. Electrical tomography results were much better (Figure 9), especially using systems with 96 electrodes and more than 2000 measurements.

Such methods, however, require large spaces that are not always available, as well as particular care during data acquisition along roads with asphalt, waste materials and pipelines. When the necessary space was not available, seismic tomographies in boreholes were carried out using hydrophone chains. This method produced interesting results. Even though it was expensive due to the requirement to drill properly equipped boreholes, the method produces information of greater detail along the investigated profiles. Further, it is crucial in ascertaining the presence of unknown cavities after the reclaiming operations.

The large amount of data collected in the last few years has demonstrated that geophysical surveys are useful for obtaining information about the presence of underground cavities. Nevertheless, the possibility of wrong indications or not detecting cavities cannot be excluded. For this reason the indirect surveys are not sufficient alone to provide data for definitively excluding the presence of cavities, and thus cannot be used to ensure safety in building design. On the other hand, when compared and integrated with data from other sources and methodologies, they may play a significant role, especially as regards analysis of large areas, and to support decisions.

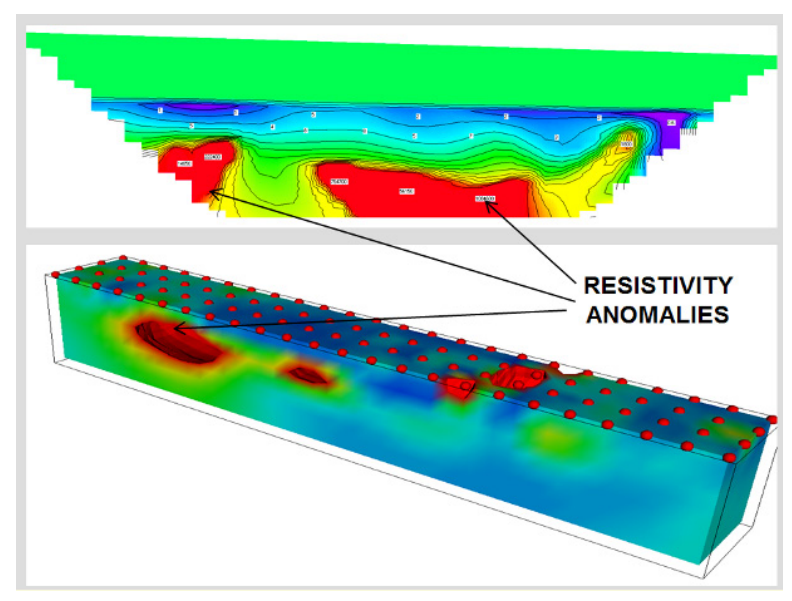

Figure 9. Example of geophysical survey for the detection of underground cavities. 


\section{Caving and topographic surveys}

Caving activities were mainly designed to explore and map the underground cavities and related projections at the land surface, in order to verify any possible interaction with the man-made environment. To this end, a surface topographic system was established to precisely locate the accesses of the quarries. Starting from this system, the underground network was then mapped together with the built-up areas.

The caving activities carried out in the territory of Altamura have been crucial for land use planning and control, and in the land management as well. The Register of Underground Cavities has been established at the Altamura Municipality, according to regulations issued by the Basin Authority of Basilicata (Berardi et al., 2010).

In particular, surveys carried out by cavers were compared with land use maps, and the zonation in different areas of risk has been implemented, with the identification of those sectors considered at high risk (classified as R4).

This approach avoids using only geophysical anomalies to locate cavities, which can be inadequate, thus permitting better designs of the stabilization works. Further, survey and graphical representation methods have evolved in the last three years. The documentation on subterranean voids is not simply provided as graphic data, since practitioners and local authorities need extremely precise information to properly work in highly urbanized areas. Therefore, the underground surveys must be accompanied by the surface topographic network.

\section{Data management and models of interpretation}

A GIS-based system was used to manage data associated with the underground quarries (Figure 10), and to highlight the most important data. These include plan views of the cave boundaries, which are basic information for planning any operational activities. The precise locations of narrow passages within the subterranean network are critical to choosing optimal sites for filling of underground voids.

\section{Data collection and geo-database implementation}

Using data available at the Technical Office of the Altamura Municipality, a geo-database was developed.
Specifically, a protocol for data acquisition was established aimed at putting all the relevant information in a GIS environment, adopting the convention of WGS 84 coordinates. Data have been sub-divided into seven thematic groups (feature datasets) that comprise specific layers of the database (Table 2).

\section{Multi-criteria approach in the definition of the sinkhole spatial hazard}

In order to map sinkhole spatial hazards, some criteria of exclusion, repulsion, and attraction (ERA) have been defined by assigning values to the land attributes in the database. In this way thematic maps were created, to which a weight was then given. Such an approach is not only important for describing and characterizing the territory, but is also aimed at determining those areas that are particularly affected by the phenomena and therefore require particular attention, especially with respect to the design of monitoring and/or alert systems.

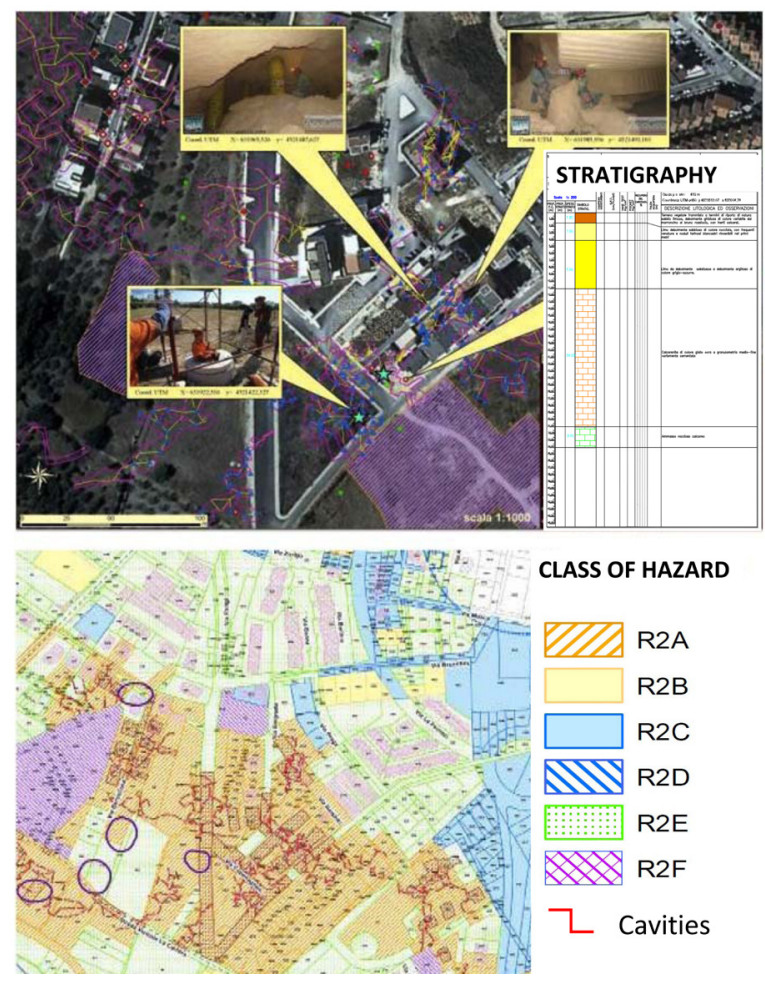

Figure 10. Screen views of the GIS system implemented for management of the cavity register. 
Table 2. Structure of the thematic groups and related layers.

\begin{tabular}{|l|l|}
\hline thematic groups & informative layers \\
\hline CARTOGRAPHY & $\begin{array}{l}\text { topography } \\
\text { building } \\
\text { cadaster (as of 2011) }\end{array}$ \\
\hline TERRITORIAL DATA & land use \\
\hline GEOMORPHOLOGY & $\begin{array}{l}\text { lithotypes } \\
\text { faults } \\
\text { terrace } \\
\text { morphology } \\
\text { sinkholes }\end{array}$ \\
\hline HYDROLOGY & $\begin{array}{l}\text { flooding areas } \\
\text { endhoreic catchments } \\
\text { hydrographic network }\end{array}$ \\
\hline SURVEYS & $\begin{array}{l}\text { direct surveys } \\
\text { stratigraphies } \\
\text { indirect surveys } \\
\text { anomalies }\end{array}$ \\
\hline CAVING ACTIVITY & $\begin{array}{l}\text { cave exploration } \\
\text { cave mapping } \\
\text { recognition of failures } \\
\text { excavation direction }\end{array}$ \\
\hline CONSTRAINTS & PAI 2010 \\
\hline OTHER DATA & $\begin{array}{l}\text { cadastral data } \\
\text { protocols } \\
\text { technical office data } \\
\text { etc. }\end{array}$ \\
\hline
\end{tabular}

To summarize, the tools used have been:

- a multi-criteria analysis to identify the most vulnerable areas and develop a zonation based on susceptibility to sinkholes;

- overlay mapping for spatial analysis.

The variables used to define the susceptibility map to sinkholes are:

1. Presence of cavities;

2. Presence of underground failures;

3. Depth of cavities;

4. Lithotypes;

5. Land use;

6. Surface hydrography;

7. Presence of faults;

8. Seismicity.

Some features such as tectonics and seismicity have not been taken into account because they are not available or homogeneous over the whole area.
The multi-criteria analysis (Malczewski, 1999) was carried out using the comparative matrix of coupled informative layers (Saaty, 1980). Through this procedure the following data layers necessary to produce the hazard map were identified:

- Presence of cavities

- Underground failures

- Cavity depths

- Land use

- Hydrogeology

Elaboration and digital overlaying of the individual data layers have produced the sinkhole spatial hazard map (Figure 11). This map is being used to identify the sectors that most need mitigation measures, taking into account all possible interactions between the spatial characteristics and potential susceptibility.

Values with respect to criteria of exclusion, repulsion, and attraction were assigned to each theme with respect to its relative contribution in terms of susceptibility. The coupled themes were put into a comparison matrix, in order to determine relative weights (Table 3 ).

All the maps are in raster format, and, by assigning them weights, it was possible to sum the pixel values and obtain the sinkhole susceptibility map (Figure 11), with a maximum value of 60 (greatest susceptibility).

\section{Conclusions}

The municipality of Altamura, like many towns in Apulia, is underlain by a long underground network of caves that are the cause of sinkhole formation, which threaten the stability of buildings and other infrastructure. Unique to the region, a process of collecting, managing and disseminating data about the underground environment at Altamura has begun, with a goal of obtaining all the information necessary for reclaiming the sites. The data are being managed in a GIS environment. Such data organization is crucial for identifying sites that are most prone to sinkholes. This work provides a starting point to support mitigation measures and appropriate management of a highly urbanized setting.

In a region such as Apulia, which is highly affected by sinkhole problems related to anthropogenic cavities (Delle Rose et alii, 2004; Fiore, 2006; Barnaba et al., 2010), and particularly to subterranean quarries (Parise 
Table 3. Matrix of paired comparison with the weight of the thematic maps ('normalized value on base 1).

\begin{tabular}{|c|c|c|c|c|c|c|c|c|c|c|c|c|c|c|c|c|c|}
\hline & \begin{tabular}{l|}
1 \\
- \\
2
\end{tabular} & $\begin{array}{l}1- \\
3\end{array}$ & $\begin{array}{l}1- \\
4\end{array}$ & $\begin{array}{l}1- \\
5\end{array}$ & $\begin{array}{l}1- \\
6\end{array}$ & $\begin{array}{l}2- \\
-3\end{array}$ & $\begin{array}{l}2- \\
4\end{array}$ & $\begin{array}{l}2- \\
5\end{array}$ & $\begin{array}{l}2- \\
6\end{array}$ & $3-4$ & $\begin{array}{l}3- \\
5\end{array}$ & $\begin{array}{l}3- \\
6\end{array}$ & $\begin{array}{l}4- \\
5\end{array}$ & $\begin{array}{l}4- \\
6\end{array}$ & $5-6$ & & WEIGHTS \\
\hline 1 - Cavities map & 0 & 1 & 1 & 1 & 1 & - & - & - & - & - & - & - & -- & - & - & 4 & 0.266 \\
\hline $\begin{array}{l}2 \text { - Map of } \\
\text { failures in the } \\
\text { cavities }\end{array}$ & 1 & - & - & - & - & 1 & 1 & 1 & 1 & - & - & - & - & - & - & 5 & 0.333 \\
\hline $\begin{array}{l}3 \text { - Land use } \\
\text { map }\end{array}$ & - & $\mathbf{0}$ & - & - & - & $\mathbf{0}$ & - & - & - & 0.5 & $\mathbf{0}$ & 1 & - & - & - & 1.5 & 0.1 \\
\hline $\begin{array}{l}4 \text { - Depht of } \\
\text { cavities }\end{array}$ & - & - & $\mathbf{0}$ & - & - & - & $\mathbf{0}$ & - & - & 0.5 & - & - & 1 & 1 & - & 2.5 & 0.16666 \\
\hline $\begin{array}{l}\text { 5- Geologic and } \\
\text { hydrologic map }\end{array}$ & - & - & - & $\mathbf{0}$ & - & - & - & $\mathbf{0}$ & - & - & 1 & - & 0 & - & 1 & 2 & 0.13333 \\
\hline \multirow[t]{2}{*}{$\begin{array}{l}6 \text { - Informatic } \\
\text { layer }\end{array}$} & - & - & - & - & $\mathbf{0}$ & - & - & - & 0 & - & - & 0 & - & 0 & $\mathbf{0}$ & & $\mathbf{0}$ \\
\hline & & & & & & & & & & & & & & & Tot. & 15 & 1 \\
\hline
\end{tabular}

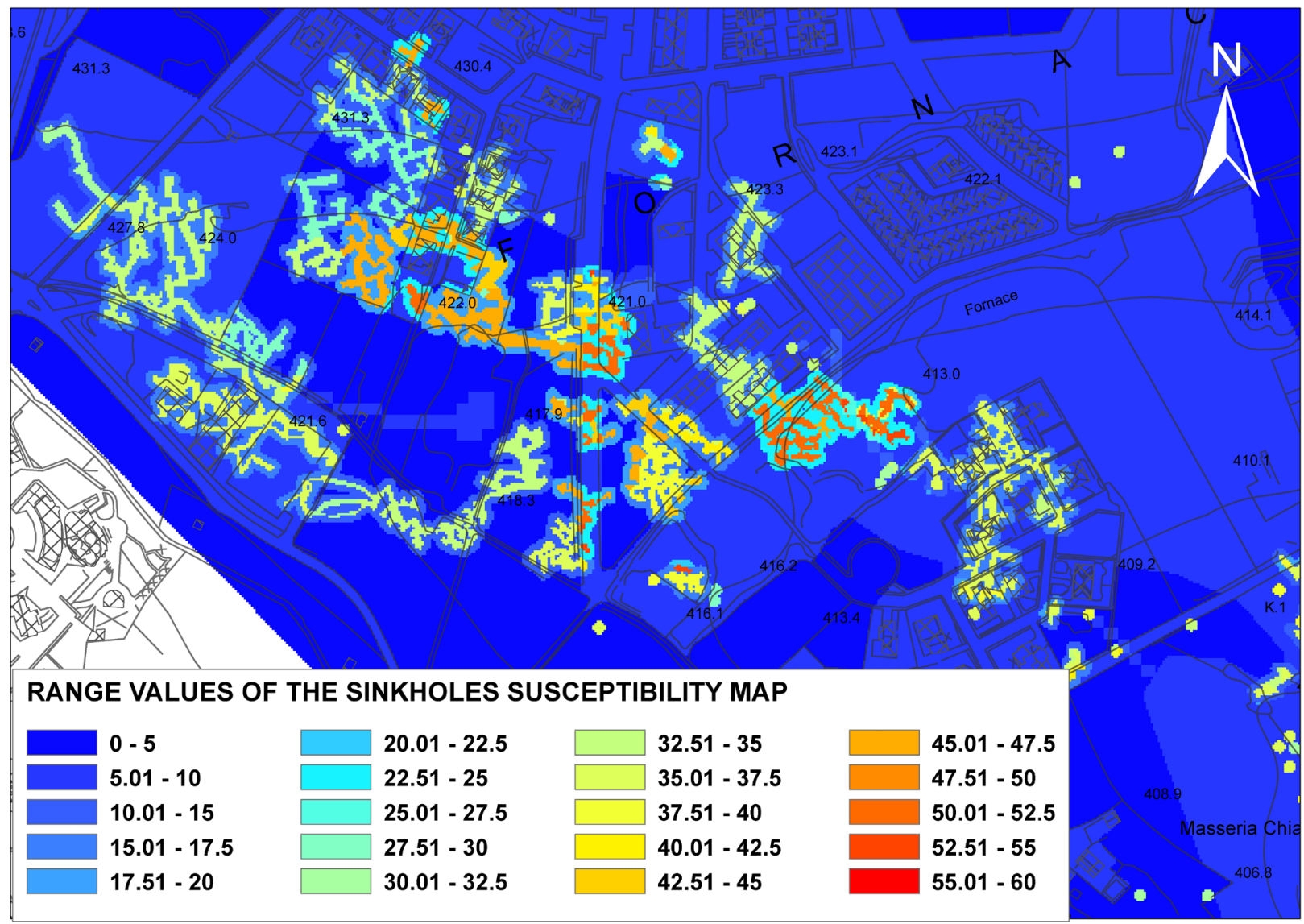

Figure 11. Extract from the sinkhole susceptibility map. 
\& Lollino, 2011; Parise, 2010, 2012), the methodology developed at Altamura provides an example to follow. This is especially true in light of the fact that a new law was recently issued by the Regional Government, that for the first time takes into account the artificial cavities and establishes pre-requisites for possible tourist exploitation of the caves, once their stability conditions have been fully ascertained (Fiore et al., 2011).

\section{References}

Azzaroli A, Perno U, Radina B. 1968. Note illustrative della Carta Geologica d'Italia alla scala 1:100.000, F. 188 Gravina di Puglia. Servizio Geologico d'Italia, Roma, 57 pp.

Barnaba F, Caggiano T, Castorani A, Delle Rose M, Di Santo AR, Dragone V, Fiore A, Limoni PP, Parise M, Santaloia F. 2010. Sprofondamenti connessi a cavità antropiche nella regione Puglia. Proc. 2nd Int. Workshop "I sinkholes. Gli sprofondamenti catastrofici nell'ambiente naturale ed in quello antropizzato", Rome, 3-4 december 2009: p. 653-672.

Berardi C, Buonamassa G, Denora A, Fiore A, Lorusso G, Pepe P, Walsh N, Zaccaria V. 2010. Attività di censimento per la pianificazione nelle aree interessate da cavità antropiche. Il Catasto delle Cavità Sotterranee (CCS) di Altamura (BA). Un modello litotecnico e di comportamento previsionale. Proc. 2nd Int. Workshop "Gli sprofondamenti catastrofici nell'ambiente naturale ed in quello antropizzato", Rome, 3-4 december 2009: p. 673-683.

Ciaranfi N, Pieri P, Ricchetti G. 1988. Note alla carta geologica delle Murge e del Salento (Puglia centromeridionale. Memorie Società Geologica Italiana 41: 449-460.

Coop MR, Atkinson JH. 1993. The mechanics of cemented carbonate sands. Geotechnique 43 (1): 53-67.

Delle Rose M, Federico A, Parise M. 2004. Sinkhole genesis and evolution in Apulia, and their interrelations with the anthropogenic environment. Natural Hazards and Earth System Sciences 4: 747-755.

Dobereiner L, De Freitas MH. 1986. Geotechnical properties of weak sandstones. Geotechnique 36 (1): 79-84.

Fiore A. 2006. Pericolosità geologica connessa alla presenza di cavità sotterranee. Atto di indirizzo dell'Autorità di Bacino della Puglia. Geologi \& Territorio, 1-2-3: 3-11.

Fiore A, Parise M. in press. Cronologia degli eventi di sprofondamento in Puglia, con particolare riferimento alle interazioni con l'ambiente antropizzato. Memorie Descrittive Carta Geologica d'Italia.
Fiore A, Martimucci V, Parise M. 2011. Nuove opportunità per la conservazione e valorizzazione delle cavità artificiali in Puglia. Opera Ipogea 1/2: 187-192.

Iannone A, Pieri P. 1982. Caratteri neotettonici delle Murge. Geologia Applicata e Idrogeologia 18: 147-159.

La Gioia R, Nova R. 1995. An experimental and theoretical study of the behavior of a calcarenite in triaxial compression. Geotechnique 45 (4): 633-648.

Malczewski J. 1999. GIS and Multicriteria Decision Analysis. New York, John Wiley.

Martimucci V, Ragone G, Denora A, Cristallo F. 2010. Le cave di tufo di Altamura - Prime relazioni e notizie sulle esplorazioni. Proc. XII Reg. Meeting Speleol. "Spelaion 07", Altamura, 7-9 december 2007: p. 91-102.

Parise M. 2010. The impacts of quarrying in the Apulian karst. In: Carrasco F, La Moreaux JW, Duran Valsero JJ, Andreo B. editors. Advances in research in karst media. Springer: pp. 441-447.

Parise M. 2011. Surface and subsurface karst geomorphology in the Murge (Apulia, southern Italy). Acta Carsologica 40 (1): 79-93.

Parise M. 2012. A present risk from past activities: sinkhole occurrence above underground quarries. Carbonates and Evaporites 27 (2): 109-118.

Parise M, Lollino P. 2011. A preliminary analysis of failure mechanisms in karst and man-made underground caves in Southern Italy. Geomorphology, 134 (1-2): 132-143.

Pieri P, Sabato L, Tropeano M. 1996. Significato geodinamico dei caratteri deposizionali e strutturali della Fossa Bradanica nel Pleistocene. Memorie Società Geologica Italiana, 51: 501-515.

Ricchetti G, Ciaranfi N, Luperto Sinni E, Mongelli F, Pieri P. 1988. Geodinamica ed evoluzione sedimentaria e tettonica dell'Avampaese Apulo. Memorie Società Geologica Italiana, 41: 57-82.

Saaty TL. 1980. The Analytic Hierarchy Process. New York, McGraw-Hill.

Spilotro G, Specchio V, Pepe P. 2010. L'evento del 07.05.2007 di Via Barcellona, Altamura. Il contributo del CARS alle strategie d'intervento di valutazione del rischio connesso (Provincia di Bari, Puglia). Proc. XII Reg. Meeting Speleol. "Spelaion 07”, Altamura, 7-9 december 2007: pp. 103-107.

Tropeano M, Sabato L. 2000. Response of PlioPleistocene mixed bioclastic-lithoclastic temperatewater carbonate systems to forced regressions: the Calcarenite di Gravina Formation, Puglia, SE Italy. In: Hunt D, Gawthorpe RL. editors. Sedimentary responses to forced regressions. Geological Society of London, spec. publ. 172: pp. 217-243.

Waltham T, Bell F, Culshaw M. 2005. Sinkholes and subsidence. Karst and cavernous rocks in engineering and construction, pp. 382, Springer Praxis. 


\section{NCKRI SYMPOSIUM 2 13TH SINKHOLE CONFERENCE}

